This article was downloaded by: [University of Western Ontario]

On: 11 February 2015, At: 00:06

Publisher: Routledge

Informa Ltd Registered in England and Wales

Registered Number: 1072954 Registered office: Mortimer House, 37-41 Mortimer Street, London W1T 3J H, UK

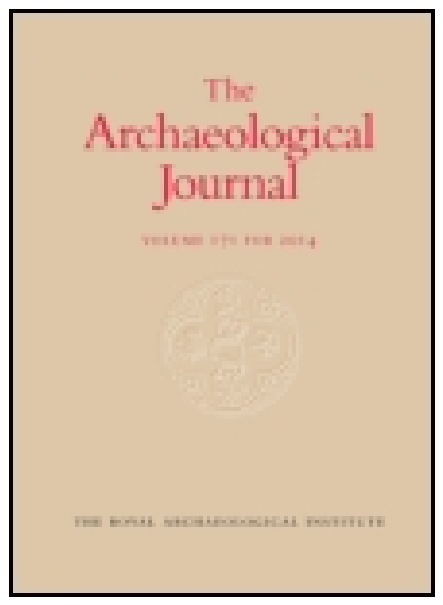

Archaeologica J ournal

Publication details, including instructions for authors and subscription information:

http://

www. tandfonline.com/ loi/raij 20

Examples of

Mediæval Seals. Illustrations of the 


\section{Mode of}

Sealing En

Placard

F. Madden \& W. S.

Walford

Published online:

$10 \mathrm{~J} \mathrm{ul} 2014$.

To cite this article: F. Madden $\&$ W. S.

Walford (1854) Examples of Mediæval Seals.

Illustrations of the Mode of Sealing En Placard,

Archaeological J ournal, 11:1, 261-272, DOI:

10.1080/00665983. 1854.10850942

To link to this article: http://

dx. doi. org/ 10.1080/ 00665983. 1854. 10850942

\section{PLEASE SCROLL DOWN FOR ARTICLE}

Taylor \& Francis makes every effort to ensure the accuracy of all the information (the "Content") contained in the publications on our platform. However, Taylor \& Francis, our agents, and our licensors make no representations or warranties whatsoever as to the accuracy, completeness, or suitability for any purpose of the Content. Any opinions and views expressed in this publication are the opinions and views of the authors, and 
are not the views of or endorsed by Taylor $\&$ Francis. The accuracy of the Content should not be relied upon and should be independently verified with primary sources of information. Taylor and Francis shall not be liable for any losses, actions, claims, proceedings, demands, costs, expenses, damages, and other liabilities whatsoever or howsoever caused arising directly or indirectly in connection with, in relation to or arising out of the use of the Content.

This article may be used for research, teaching, and private study purposes. Any substantial or systematic reproduction, redistribution, reselling, loan, sub-licensing, systematic supply, or distribution in any form to anyone is expressly forbidden. Terms \& Conditions of access and use can be found at http://www.tandfonline.com/page/terms-andconditions 


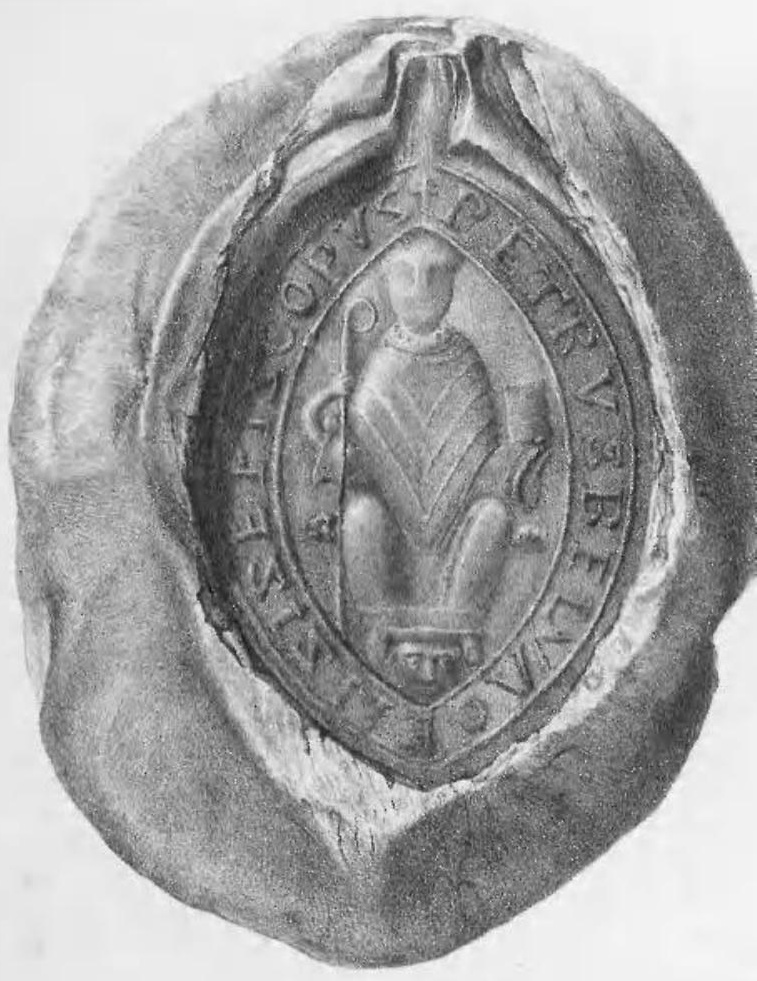

Seal of Peter, Bashop of Beauvais, A D jla3.

G.H.Ford. 


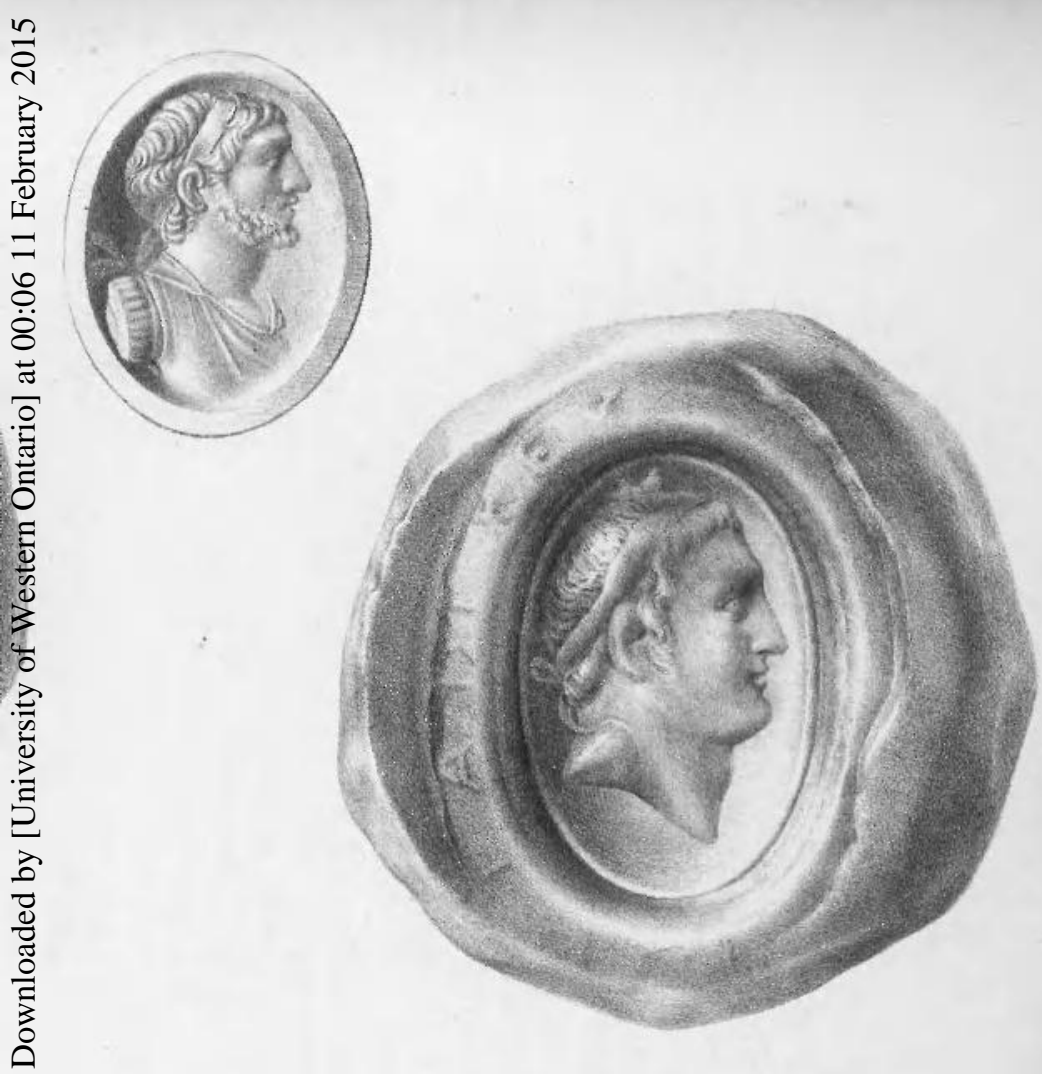

Sical of Euras Fing of Fracce, AD, 888-9 the mode of sealing en placard. 
EXAMPLES OF MEDIFVAL SEALS. ILLUSTRATIONS OF THE MODE OF SEALING EN PLACARD.

REMARKS ON A SEAT AND OHARTER OF EUDES, KING OF FRANOE, OF THE

YEAR 888 OR 889 .

THE recent acquisition by the Department of MSS. in the British Museum of an original charter of Odo (or Eudes) king of France, executed in the year 888 or 889 , to which a seal en placard, in remarkably fine preservation, is affixed, affords a favorable opportunity of making some remarks in illustration of this mode of sealing, as also on the seal and charter of Eudes, which is now marked $A d d$. Chart. 8516, in the National Collection. It is well known that the usage of affixing a seal of wax to the royal diplomas was practised in France by all the kings of the first two races, and continued by the earlier Capetian monarchs. With the exception, indeed, of such documents as were sealed with a metallic bulla, either of gold or lead (which on account of the material was obliged to be suspended), it may be assumed with certainty, that no other mode of attaching the seal to regal instruments prevailed in France from the reign of Clovis I.A.D. 481, to the reign of Louis le Gros, A.D. 1108. In the reign of Louis, the practice of appending the royal seal was first introduced, ${ }^{2}$ but not entirely to the exclusion of the former mode ; and even after this period instances of the seal plaque are still occasionally to be met with, both in France and Germany, to the close of the twelfth century.

It would appear very remarkable, that during the long interval of time which elapsed from the settlement of the Heptarchy to the reign of Edward the Confessor, the AngloSaxon sovereigns should have contented themselves with making a simple cross to authenticate their charters, and

1 It was purchased at a public auction at Messrs. Sutheby and Wilkinson's, in January, 1854, Lot 100, and is supposed to have been transferred with other MISS. for sale from Paris.
2 'The solitary instance noticed by the Benedictines, Nouv. Traite, iv. 400 , of a seal of Robert II. appended, A.D. 1025, even if genuine, does not affect the accuracy of the proposition above. 
not rather have imitated the Frankish fashion of sealing; but such seems to be the fact, except in three well authenticated instances to the contrary (on which some observations may on another occasion be offered), namely, in the grants of Offa, Ethelwulf, and Edgar, to the Abbey of St. Denis, all of which, in compliance with the French usage, were sealed en placard. And it is also worthy of notice, that the seals of Edward the Confessor, (the first of the English kings who used commonly a seal) were always appended to the charter, and afford earlier examples of that mode of sealing than are to be met with in the royal charters of France. The practice, indeed, of affixing the seal was not introduced into England until the fourteenth century (when it was also revived in France), and then only in regard to a.special class of public instruments.

The charter of Eudes which has occasioned these remarks, is written on a sheet of parchment $19 \frac{1}{4}$ inches in width by 21 inches in height, and contains a grant of a portion of the royal demesne, situated at Jouy (Gaugiacum), on the river Eure, two leagues to the north of Chartres, to a certain Ricbodo, styled "fidelem nostrum ;" to be held beneficially for the term of his life, or, should he marry and have a son, for the term of their three lives. On the back of the charter are several indorsements in different hands, one of which may be of the 13th century, "p'ceptu de ioiaco," but the remainder are in hands of the last century. One of them is as follows, "Tiltre de Eudes, Roy de France, touchant Jouy, l'an 896. Casse neufiesme;" and another, "Bercheres la Maing $[\mathrm{r}]$ ot. Jouy. $1^{\text {re }}$ liasse, de l'an 892. Titre de Eudes, roy de France, par lequel il donne a Ricbodon et sa femme et a son fils, pendant leur vie durante, un fief assis au pays Chartraine, sur la riviere d'Eure, au village de Jouy, contenant le dit fief trente fermes ou maisons, que tient en bénéfice le dit Ricbodon." This document is not unknown to the French historians, having been printed by Mabillon in 1681, in his work De Re Diplomatica, p. 556, (edit. 1789 , p. 576), and thence reprinted in vol. ix. p. 446, of Dom Bouquet, 1757, but in both cases with some remarkable errors of transcription. A very exact and literal copy is therefore here annexed. 
[Monogrammatic invocation. $\left.{ }^{3}\right]$ (1). IN NOMINE SCÄE ET INDIUIDUAE TRINITATIS ODO CLEMENTIA Dİ REX $\vdots$ REGALIS CELSITUNIS " MOS EST FIDELES REGNI SUI DONIS MULTIPLICIBUS ATQUE HONORIBUS INGENTIBUS (2) honorare sublimesque efficere: Nouerit igitur omnium fidelium scae di ecclesiae nrorumque ${ }^{3}$ tam praesentium quam \& futurorum sollertia. $\mathrm{qm}^{6}$ placuit serenitati nrae quendam fidelem nrm (3) nomine ricbodonem de quibusdam rebus nrae propria\&atis honorare. sunt autem eedem res in pago carnotensi sup fluuium oduram in uilla gaugiaco mans ${ }^{7}$ in dominicatus ubi aspiciunt (4) mansa triginta unum quos p'dictus ricbodo in beneficium tenet. $\mathrm{Hoc}^{8}$ itaque beneficium iam dicto fideli ñ̃o iure beneficiario \& usu fructuario concedimus quatenus dum quilibet ricbodo \& quando (5) quidem dó disponente uxorem duxerit \& exinde filium procreauerint \& unus ex illis aduixerit. iam dictum beneficium teneant atque possideant nemine inquia\&ante. Unde hoc nrae celtitudinis ${ }^{9}(6)$ praeceptum fieri \& memorato fideli nr̃o dari iussimus per quod p'cipimus atque iubemus ut ab hodierna die iam dictus fidelis n ricbodo supa scriptum beneficium teneat uxorque (7) \& filius eius dum aduixerint disponant usu quidem ut dictum est fructuario \& iure beneficiarium ${ }^{1}$ omni tempore uitae suae eo siquidem tenore ut aliquis eorum in nr̃a fidelitate semp ( 8 ) \& defensione ${ }^{2}$ pro eorum beneficio deseruiat. Et ut haec nrae largitionis concessio ita in omnibus conseru\&ur atque uerius credatur anulo nro insigniri iussim.

\section{(9) Throhannus ${ }^{3}$ notarids RECOGNOUIT ${ }^{5}$. \\ ADUICEM \\ EBLONIS ${ }^{4}$

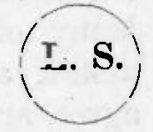
dat $x v I$ kt iut indict $v I^{2}{ }^{6}{ }^{6}$

3 Several examples of this abbreviated form are engraved in the Nowveau Traite de Diplomatique, tom. iv., pl. 72, p. 608. There is no doubt that originally it included the words In Christi nomine, but by degrees it came to be an unmeaning flourish. See Silvestre's Palaegraphy, English edition, vol. ii., pp. 458, 465 .

${ }^{4} \mathrm{~A}$ mistake of the scribe for celsitudinis, and so printed by Mabillon and Bouquet.

5 et nosirorum, in $\mathbf{M}$, and $\mathbf{B}$.

6 quoniam.

7 Printed mansus in M. and B.

8 Nos, M. and B.

9 celsutudinis, M. and B.

1 beneficiario, M. and B.

2 devotione, $\mathrm{M}$, and $\mathrm{B}$.

3 Read Crohannus by Mabillon in his fac-simile, tab. xxxiv. According to the authors of the Gallia Christiana, vol. viii., col. 1427, he is the same with Throannus, Bishop of Orleans. Mabillon, Suppl. p.
$47,(1704)$ is of the same opinion, but at p. 412 , of his work (edit. 1709) he throws a doubt on this identity, apparently, without reason. In the charters of $\mathrm{Odo}$, printed by Bouquet, Throannus appears as Notary or Vice-Chancellor from A.D. 888 to A.D. 892 . De Wailly, Elements do Paleographie calls him Troannus or Rohannus, which last is erroneous.

4 Ebonis, M.-Eblo or Ebles was chancellor to Eudes, and abbot both of St. Germain des Pres and St. Denis. He died in 893 . See Felibien, Hist. de St. Denis, p. 100, and De Wailly, i. p. 224.

5 recognovit et subscripsit, $M$, and $B$. In Mabillon's fac-simile the word is copied falsely recognouiets. The words et subscripsit are, in the original, included in the paraphe or flourishes round the seal, written before the wax was applied.

6. In Bouquet, it is conjectured that this is an error for indict. vi. 
Odoni gloriosissimo rege. Actũ sčo maximino monasterio ${ }^{7}$ in $\mathrm{d} \tilde{\mathrm{i}}$ nomine feliciter amen.

In respect to the date of this charter, some difficulty exists. Mabillon reckoned the accession of Eudes from the death of Charles le Gros, 12th January, 888, and assigns the document to A.D. 889. In Bouquet, the accession of Eudes, as well as the charter, is placed in the same year, A.D. 888, and the editors adopt the opinion of Vaissette, that two epochs of this reign must be admitted, one taken from 887 , and the other from $888 .^{8}$ De Wailly says, that Eudes was elected king after the deposition of Charles le Gros, which took place 11 th November, 887 , but argues also in favor of the adoption of two epochs. But supposing this to be true, it is not very obvious how the second regnal year of Eudes can be included in any part of 888 previous to November, unless the fraction of the year 887 is to be reckoned as the first of the reign, and the second and succeeding years calculated from the 1st of January. ${ }^{9}$ The charters of Eudes, as printed in Bouquet, do not afford much assistance in clearing up the question, for there is great reason to doubt the accuracy of the transcripts, exclusive of the errors committed by the original scribes. Many of these charters have the year of the incarnation added, as well as the indiction, but these do not always agree, and the Benedictines have not scrupled to correct the latter frequently. The seventh indiction, as expressed in the charter to Ricbodo, points to the year 889 , with which the second year of the reign of Eudes will well correspond; but it must not be concealed that other charters of Eudes (Nos. 3 and 4 in Bouquet) are dated at St. Mesmin in June, 888, the second year of his reign and siath indiction. Yet, on the other hand, Nos. 9 and 10 in Bouquet are dated in July, 889 , in the second year of his reign, and sixth indiction. It must therefore be left a matter of uncertainty, whether the

7 The monastery of St. Maximin at Micy (otherwise called St. Mesmin) near Orleans.

8 See the Monitum prefixed to the charters of Eudes, Recueil des Historiens de la France, tome ix., p. 439.

9 A document is referred to in Bouquet, dated "A.D. 888, indict. 6. sub anno primo imperii Odonis, $12 \mathrm{kal}$. Maii [20 Apr.] epact. 14," which would lead one to infer that the first regnal year was computed from November, 887, to November, 888. If a table of the reign of Eudes were calculated on this principle to the date of his death in January, 898 , it will be found that the years are ten in number, and two months over, while the indictions extend from 5 to 15 of one cycle and 1 of the cycle following; yet on testing the charters by such a table, it will be impossible to reconcile them, without considerable corrections. 
charter now in the British Museum was granted in 888 or 889 , but $\mathrm{I}$ would rather incline to the latter date.

When Mabillon printed this charter in 1681 , the original was preserved among the muniments of the cathedral of Chartres, but of its subsequent history nothing has been learnt. In Tab. xxxiv., p. 413, he gives a fac-simile of the first, ninth, and tenth lines of the document, with a very incorrect outline engraving of the seal, of which he says, p. 138, "Odonis regis sigillum ex diplomate ecclesiæ Carnutensis expressum, potius vetus aliquod numisma quam ipsius Odonis imaginem præferre videtur :" and again, at p. 412, "Specimen hoc ex autographo cathedralis ecclesiæ Carnutensis expressum est, cum sigillo, quod nescio an Odonis representet effigiem, an cujusdam Imperatoris Romani." But having subsequently met with another seal of Eudes affixed to a charter preserved at Autun, and dated 10 kal. July, A.D. 890, indict. 8 , in the third year of the king's reign, he engraved it in his Supplement, p. 47 , published in 1704 ; and in the second edition of his work, which appeared in 1709 , the passages above stated are altered, and the latter thus appears, p. 412, "Specimen hoc \&c., cum sigillo, quod an ipsius Odonis effigiem repræsentet, olim mihi dubitatio injecta est, propterea quod nullum lemma in archetypo Carnutensi apparebat. Verum hanc dubitationem prorsus sustulit aliud ejusdem Odonis authenticum, asservatum in archivo ecclesiæ Augustodunensis, omnino sanum et integrum, in quo hoc lemma in circulo legitur, ODO GRATIA Di REX, quo ex sigillo apparet virum eximiæ formæ fuisse." By the fault of the artists employed, and want of due examination and comparison on the part of Mabillon, he has been led to consider these two seals as wholly different, but there is every reason to believe that the impressions are both taken from the same matrix. By the drawing in the annexed plate, fig. 1, now for the first time correctly made from the seal of the charter to Ricbodo, it will be seen how little dependence can be placed on Mabillon's engravings, and how blindly his authority has, in this respect, been followed by Montfaucon, the authors of the Nouveau Traite, De Wailly, and many other writers on palæography and antiquities. The inscription round this seal (erroneously stated by Mabillon not to exist) corresponds, as far as can be read, with the one affixed to the Autun charter, and, allowing for the circumference of the wax, it is of the same 
size. The impression itself measures 2 inches by $2 \frac{3}{8}$, and the seal to the edge of the wax $2 \frac{1}{2}$ inches by $2 \frac{6}{8}$. At the deepest part, the wax is above an inch in thickness. The head is a profile bust turned to the right, encircled by a tiara or fillet, and is impressed from a bold intaglio cut on a deeply convex surface. On the top of the head appears something which at first sight looks like the points of a star, but, in all probability, this arises from a flaw or injury in the original matrix. The whole character and execution of the head is obviously antique, and Mabillon's first idea that it was an impression from an ancient gem, is, no doubt, correct. Instead, however, of being of Roman art, it represents the features of a Greek sovereign, probably of Syria or Egypt, and a great similarity may be observed in the treatment of this bust with that displayed on the coins of Seleucus IV. The mode in which one string of the tiara (omitted by Mabillon) is brought round the top of the shoulder, as on the coins, is particularly remarkable. That an ancient gem, surrounded by an inscription foreign to its design, should have been used by Eudes for a seal, is by no means to be considered singular. It is well known, that the employment of gems and engraved stones in sealing was practised at an early period, and the instances of the heads of the Indian Bacchus and of Jupiter Serapis, used by Pepin le Bref and Charlemagne, afford examples which cannot be questioned. ${ }^{1}$ We may, however, go a step further, and assert with some confidence, that the whole of the seals used by the Carlovingian monarchs, from Pepin le Bref, A.D. 752 -768 to Charles le Simple, A.D. 893-929 inclusive, are antique gems or pastes, cut in intaglio on a convex surface, and represent profile busts of Greek or Roman princes, instead of being portraits of the sovereigns of France, as stated by Mabillon and his followers. If, in fact, we look at the authentic seals of the Merovingian race, beginning with Thierri III., A.D. 670-691, and ending with Chilperic II., A.D. $715-720,{ }^{2}$ it is impossible not to be struck with the excessive rudeness of the full-faced, long-haired heads

\footnotetext{
1 The similar employment of an antique gem, bearing the head of Jupiter Serapis, on the ancient conventual seal of Durham, is familiar to English antiquaries, and is engraved in Smith's Bede, Appendix, p. 72. This gem is inseribed around, CAPUT SANCTI OSWALDI !
}

2 The seal of Dagobert I. is acknowledged to be a gross forgery; and so also is the seal (and charter) of Chilperic I., grandson of Clovis (engraved in the Nowveau Traite, iii. 646), although it is referred to as authentic by the Benedictines and De Wailly. 
engraved on them, which we might fancy almost to have been executed by barbarians ; and it is equally impossible to believe, that the native artists who executed these caricatures of human features, could have produced the admirable Greek head on the seal of Carloman, circa A.D. 768. Again, it is only necessary to compare the bulla used by the Carlovingian kings with their seals, to be made aware of the striking difference between the style of art exhibited in the former and the profile busts the seals of Carloman, Charlemagne, Louis le Debonaire, Lothaire, Charles le Chauve, Louis le Bègue and Charles le 'Simple. ${ }^{3}$ And further, if we take a later period, and examine the seals subsequent to Louis d'Outremer, after the middle of the tenth century, when the use of antique gems had ceased, we find on the seals of Lothaire, Robert II. and their successors, a complete middle-age type, imitated (like the bulla) from the coins and medallions of the Lower Empire, and wholly dissimilar to the Carlovingian laurelled profiles. In support of this view it may be added, that antique gems are still in existence resembling in workmanship, form, and size, the seals found on the Carlovingian charters. One of these is preserved among the Towneley gems in the British Museum, a drawing of which has been made, fig. 2 of the adjoined plate. It is an antique paste cut in intaglio on a convex surface, and represents a profile bust very similar to those on the seals of Charlemagne; so much so, indeed, that it might well have served that monarch, or one of his successors, for a signet. Yet how absurd would it be to argue on the authority of such a gem, what style of beard or hair was worn by the Carlovingian monarch, or on which shoulder his mantle was fastened! On no better grounds, however, as it would seem, have the French antiquaries (including the respectable names of Mabillon, Montfaucon, and a host of later writers) drawn minute inferences as to the costume and fashion of the Carlovingian race of princes; which, supposing the seals to be gems and not contemporary portraits, are wholly valueless, and without foundation.

3 Compare the engravings in Mabillon, pp. 145, and 146, and Nouv. Tr, iv. 112, with the Carlovingian seals engraved in De Wailly. The authors of the Tresor de Numismatique, 1834, admit the Seals of Carloman, Charlemagne, and Lothaire to be antique gems, and the latter to represent the portrait of Caracalla or Alexander Severus. 
Two other points yet remain to be considered before these remarks are brought to a close : first, the formula by which the act of sealing is indicated in the charter of King Eudes; and, secondly, the mode in which the seal itself was affixed. The formula is as follows, "anulo nostro insigniri jussimus," and this, or a similar form, is invariably used in the charters of this king, except in one instance (No.22 in Bouquet,p.460), where we read " de bulla nostra assignari," but the document seems of questionable authenticity. The term, indeed, of annulus for the seal was used throughout the Carlovingian period, almost to the exclusion of any other; and it was only in the latter reigns that the word sigillum became introduced, ${ }^{4}$ which at length, at the close of the eleventh century, usurped generally ${ }^{5}$ the place of the former term. The reason undoubtedly is, that the seals of the French sovereigns from the time of Clovis (or earlier, if we admit the genuineness of the seals of Chilperic I. $^{6}$ ) were engraven and set as rings, and so continued to be used until the reign of Louis d'Outremer, after which time the size and fashion of the seal were entirely changed, and the matrix, in consequence, became too heavy and cumbersome to be worn as a signet.

The position of the seal in the charter of Eudes is (as usual in Carlovingian diplomas) after the name of the chancellor or his deputy, and the color of the wax is white, embrowned on the surface by the combined effect of the air and dust. Previous to the wax being applied, an incision was made in the parchment, in the form of a cross or saltire, ${ }^{7}$ the edges of which were turned back, and the wax then pressed through the interstices, so as to form a cake or mass on both sides of the document, but of unequal thickness. The thinnest portion was on the back of the charter, the appearance of which, as flattened after the impression of the seal had been made on the front or obverse, is shewn on a reduced scale in the second plate. It appears that this mode of sealing en placard was found to afford the means of forgery, by enabling a person to detach the front

4 In the few charters of earlier date, where the word sigillum occurs, the document is either an acknowledged forgery, or liable to grave suspicion. See Mabillon, i. 112 , ed. 1789 .

- Not entirely, for annulus is used in a charter of Louis VII, as late as A.D. 1169.

6 See Mabillon, i. 139 ; Montfaucon, i. 10 ; Nouv. Tr. iv. 100.

7 Mabillon, i. 140 ; Nouv. Tr. iv. pl. 75, p. 396 . 
Plato 2.

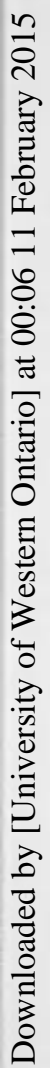

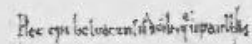
thather

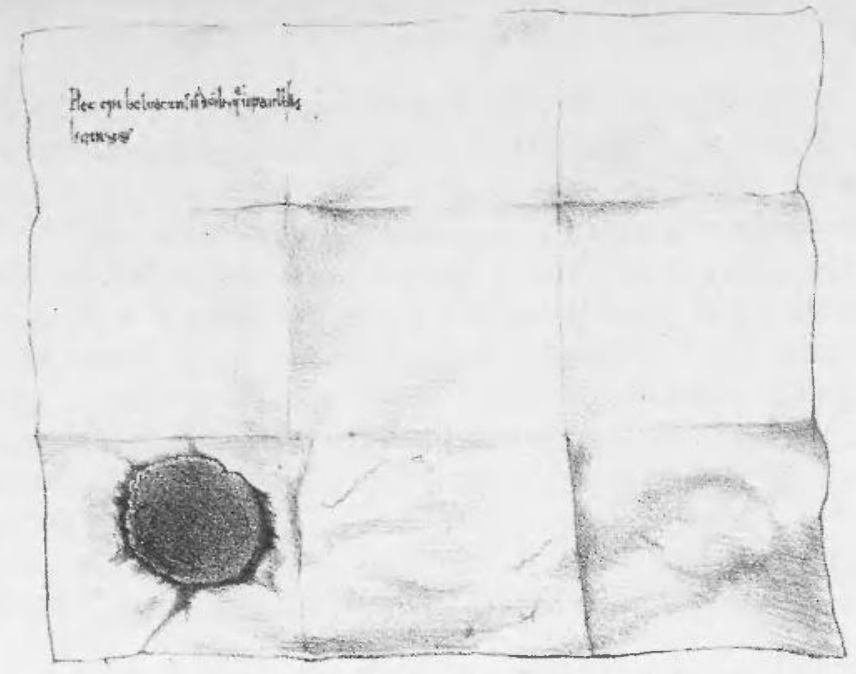

1.

$\checkmark$

Peter, Bashop of Beatwas, A D 1223

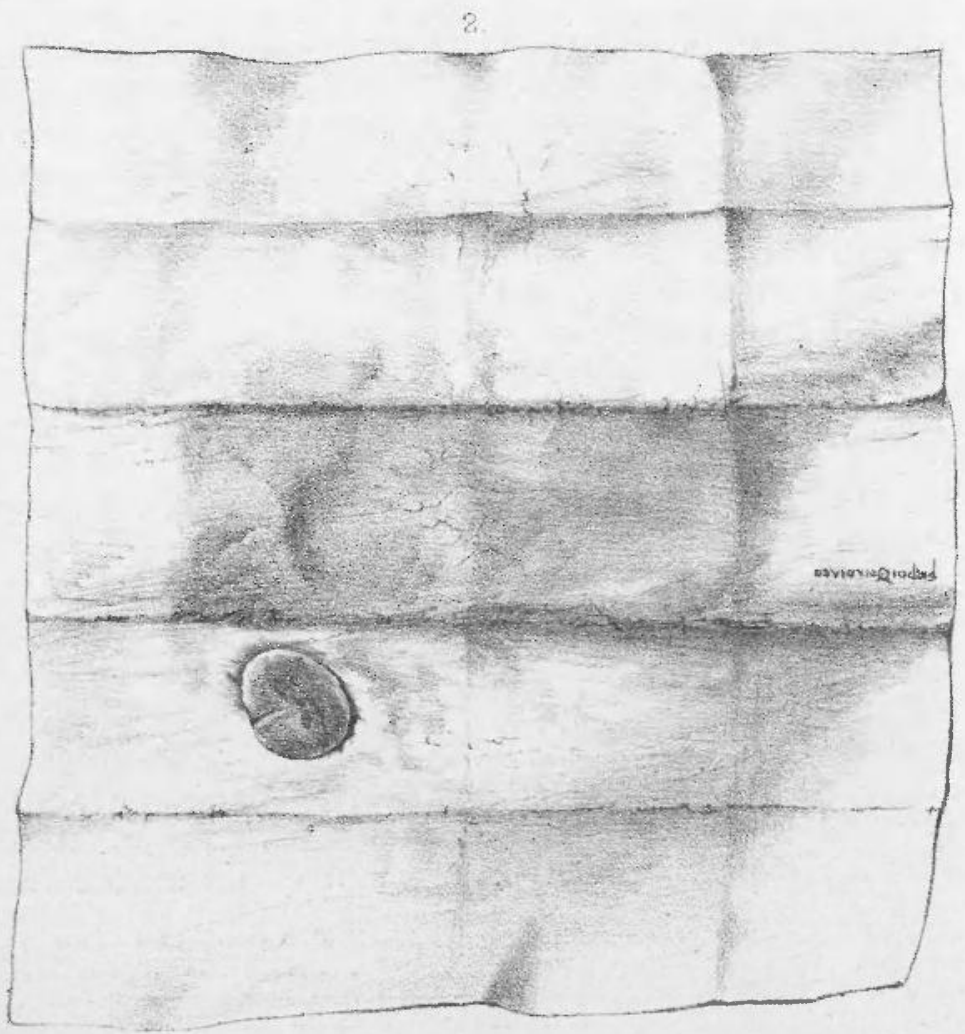

tudes Kang of Fiance, AD 888-9.

Backs of Chariers sealed en placard: length ${ }^{2} / 5$ original 
portion of the seal, and supply fresh wax beneath, as described in an epistle of Pope Innocent III., quoted by Mabillon, p. 155 ; and it was, probably, to guard against frauds of this kind, that a counterseal on the reverse of seals so made was used by the princes of Lombardy, as early as the year 901. In other parts of Europe the counterseal is of more recent usage, and was first introduced into the regal seals of France by Louis VII., A.D. 1137-1180. It would seem, that when the fashion of appending seals had become established at that period, the counterseal would naturally accompany the change.

\section{F. MADDEN.}

REMARKS ON A SEAL AND CHARTER OF PETER BISHOP OF BEAUVAIS OF THE YEAR 1123.

THE seal of Peter, Bishop of Beauvais, recently acquired by the Department of MSS. in the British Museum, furnishes another example en placard. The practice of affixing seals in that manner is said to have continued longer among bishops and abbots than with sovereigns; though even with these ecclesiastics it does not appear to have been in use after the end of the xilth century. ${ }^{8}$ There were several bishops of Beauvais named Peter; this was distinguished as Peter I. For some time his parentage and condition in life before his election to the bishopric were unknown. It now appears, according to Gallia Christiana, that he was of a noble family, and a brother of Fulk, a previous bishop of that see, who filled it from 1089 to 1095 , having been a pupil of Lanfranc, and before his election a monk at Bec, under St. Anselm, then the abbot, and afterwards, like Lanfranc, archbishop of Canterbury. There was another brother of Peter, named Ralph, who was also a monk at Bec. They were the sons of a Lancelin Count of Dammartin, in the Isle of France, and brother of Lancelin de Bulles (de Bubulis) whom the same authority calls count, and therefore he probably succeeded his father. Their grandfather is said to have been Fulk, and surnamed de Beauvais. The succession of the Counts of Dammartin in "L'Art de Vérifier les Dates" is very defective and otherwise unsatisfactory;

8 De Vaines Dict. Raisonne de Diplom, ii. 309. 
and what is above stated, on the authority of Gallia Christiana, as to the family is not easily reconcileable with it. Only one Lancelin is there mentioned, and no Fulk: the grandfather, however, of that name may have been a younger son. Peter had been a canon, and probably dean, of Beauvais before he was elected bishop in 1114. He held the see till his death in 1133, and appears to have been an active prelate in the affairs of his diocese. He was present at the councils held at Beauvais in 1114 and 1120 . In the meanwhile he had been sent by Louis VI., with the abbot of Morigny, on an embassy to Pope Calixtus II. In 1128 he was at the Council of Troyes, and in 1132 Pope Innocent II., in his progress through France, when compelled to leave Rome for a while, paid him a visit at Beauvais, about which time, if not on that occasion, the relics of Saints Just and Geremar were translated to new shrines. In the Necrologium of his church he is thus mentioned: "VI. Id. Novembr. obiit Petrus episcopus, qui dedit nobis duas domos, unam in claustro, alteram in burgo." There were other acts of his quite as memorable, but this was probably considered more likely to awaken the gratitude and win the prayers of the chapter.

The seal is attached to a charter, dated at Beauvais in $1123,{ }^{9}$ whereby Peter confirmed to the Monastery of St. Martin des Champs, Paris, on the application of Matthew the prior, all the property that had been given to them in his diocese, as well ecclesiastical as lay, saving the rights of his church : in which were comprised the church of St. Omer; the toll-traverse in Milly every tenth day of all things carried through, for which such toll was payable ; a bushel of wheat in a certain mill in "Uns," probably Onz-enBray ; the church of Meru; the church of St. Leonorius, at Beaumont; the tithe of "Meinecurte;" the church of "Cressonessart;" the land with the wood and villeins (hospitibus ${ }^{1}$ ) which the monastery had of the gift of Baldwin "de Butinangulo," and of the fee of Lancelin of Beauvais (probably a relation of the bishop), " apud Dedumulerium et

9 Add. Chart. 8535.

I The hospites, hostes of the French law, seem at this time to have differed little from our villani : they were oceupied in cultivating the soil, and were re- garded as belonging to it. The word may probably be referred to the designation given by the Burgundian invaders to the Gauls, on whom they quartered themselves, and whose lands they shared. 
apud Cupehel ;" and the land near Beaumont at Moussy (?), which was given by Waleran, the brother of Joldwin de Munci. The confirmation was made with the consent of his three archdeacons, whose names are given, and one of them, being Theobald the son of Lancelin, may have been a relation. It was delivered to two monks, we may presume from St. Martin's, one of whom, Gonfredus, is described as "qui prior fuerat ecclesiæ sanctæ Marie britoilensis." The exact signification of "prior" here is not clear. Britoilensis refers, most likely, to the Breteuil in the diocese of Beauvais, where there was an abbey of Benedictines; but "prior ecclesiæ sanctæ Marie" is not the phrase likely to have been used to express the prior of that abbey. The charter read in extenso is as follows:-

In Nomine Sancte ET Indididee Trinitatis. Quoniam mundus in maligno positus est, et iam multorum refriguit caritas, necesse est ut qui sancta presunt æcclesiæ deo seruientium paci studiosius inuigilent, non solum suis temporibus, sed etiam infuturo prouidentes: Vnde notum esse uolumus omnibus tam presentibus quam futuris quod ego petrus dei gratia beluacensis episcopus concessi monasterio sancti MARTINI de campis, precibus dunni mathei, qui tunc eiusdem loci prior erat, omnia que inepiscopatu nostro de beneficiis fidelium, tam ecclesiasticis quam laicalibus, iuste possidebat; Saluo tamen in omnibus iure beluacensis æcclesise; Ecclesiam scilicet sancti audomari cum appendiciis suis ; Transuersum de miliaco insingulis decimis diebus de omnibus rebus que transuersum reddunt; Vnum modium frumenti in quodam molendino quod est inuilla quæ dicitur vns ; Ecclesiam de meruaco cum appendiciis suis; Apud bellomontem ecclesiam sancti leonorii cum omnibus appendiciis suis ; Decimam de meinecurte; Ecclesiam de cressonessart cum omnibus appendiciis suis; Terram cum nemore et hospitibus quam habet idem monasterium de dono balduini de butinangulo et de feodo lanscelini beluacensis apud dedumulerium et apud cupehel ; Juxta bellomontem apud musiacum terram quam dedit Gualerannus frater Jolduini de munci. Hoc autem feci consilio et assensu archdiaconorum æcclesiæ nostræ, Rogeri filii lanszonis, Theobaldi filii lanscelini, atque Henrici filii henre de conti. Et ut hoc firmum et inconuulsum permaneat carta sigillo meo signata confirmaui ; Et ne aliquis has possessiones et istam confirmationem infringere et inuadere presumat sub anathemate interdixi. Data beluaciis per manus duorum monachorum, Gonfredi qui prior fuerat æcclesiæ sanctæ Marie britoilensis et dunni Alberici Anno ab incarnatione domini millesimo centesimo $\mathrm{xx}^{\mathrm{mo}} \mathrm{iii}^{\mathrm{c} 10}$.

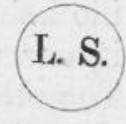

The parchment is $16 \frac{1}{4}$ inches by $13 \frac{1}{2}$; the writing, which is in the large bold hand of the time, runs in the voL. XI. 
direction of the length. There is no lateral margin, but below the writing, throughout the whole extent, is a blank space, about five inches in width, on which, near the right hand corner of the parchment, is affixed the seal. The form and size of the wax, which was white, and also of the impression, are shown in the plate. The matrix evidently had a loop for suspension, which has left an indentation above the device, as is there also shown. The subject is a bishop bareheaded, in eucharistic vestments, seated, and holding in his right hand a crosier, with the crook turned towards him, and in his left hand a book: at his feet is a lion's face. The seat terminates on each side in a bird's head. The legend is, F PETRVS BELVACINSIS EPISCOPVS; in which are noticeable the rectangular $\mathrm{E}$, and the angular forms of the $\mathrm{s}$ and $\mathrm{o}$. The A appears to want the traverse, but this may have been unintentional. The seal would seem to have been affixed by making an incision in the parchment, probably in the form of a cross or star, and folding back the corners of the incision, and passing a portion of the heated wax through the hole so formed, leaving a large mass of it on the front, and moulding another, but much smaller, lump at the back, so as to make the whole of the wax resemble a large clenched rivet. The matrix was then impressed on the mass in front, which is still about an inch in height; and the seal thus made could not be removed without injuring the parchment, or heating the wax anew. The appearance of the wax at the back, which is about $2 \frac{1}{9}$ inches in diameter, and flattened, as if by the pressure of sealing the other side, and also the puckered state of the parchment, occasioned by the process of affixing it, are shown on a reduced scale in the plate which accompanies these remarks.

The charter is numbered viII., and there are four indorsements, evidently made at different times, indicating the nature of it. The earliest, which is in a hand apparently a little later than the charter, reads in extenso as follows: "Petri Episcopi beluacencis de omnibus que in episcopatu illo habemus." Another, near the reverse of the wax, is like it, except that "habebamus" is substituted for "habemus." The others are in French, and no doubt considerably later than the charter.

W. S. WALFORD. 